\title{
ANALISIS KEBUTUHAN BAHAN AJAR MIKROBIOLOGI UNTUK MAHASISWA PROGRAM STUDI PENDIDIKAN BIOLOGI
}

\section{NEEDS ANALYSIS OF MICROBIOLOGICAL TEACHING MATERIALS FOR BIOLOGY EDUCATION'S STUDENT}

\author{
Mar'atus Sholihah' ${ }^{1)}$, Marinda Sari Sofiyana ${ }^{2)}$ \\ ${ }^{1), 2)}$ Pendidikan Biologi, Universitas Islam Balitar Blitar \\ Email: maratussholihah11292@gmail.com \\ diterima : 30 Agustus 2019; dipublikasi : 30 Oktober 2019 \\ DOI: http://dx.doi.org/10.32528/bioma.v4i2.3162
}

\begin{abstract}
ABSTRAK
Tujuan penelitian ini untuk mesdeskripsikan analisis kebutuhan mahasiswa terhadap bahan ajar mikrobiologi. Metode penelitiannya adalah deskriptif kualitatif dengan subjek 24 mahasiswa program studi pendidikan Biologi Universitas Islam Balitar yang telah menempuh mata kuliah mikrobiologi dan dosen pengampu mata kuliah mikrobiologi. Teknik pengumpulan data dengan wawancara dan angket. Instrumen yang digunakan adalah lembar wawancara untuk dosen pengampu dan lembar angket mahasiswa untuk analisis kebutuhan bahan ajar mikrobiologi. Data hasil wawancara dianalisis secara deskriptif dan data hasil angket dianalisis dengan dibuat persentase. Hasil penelitian menunjukkan bahwa belum tersedia bahan ajar untuk mata kuliah mikrobiologi dan perlu dikembangkan bahan ajar mikrobiologi berbasis gambar dan teks salah satunya yaitu atlas..
\end{abstract}

Kata kunci: Analisis Kebutuhan, Bahan Ajar, Mikrobiologi, Atlas

\begin{abstract}
This research aims at describing the analysis of students' needs for Microbiology teaching materials. This research adopted a qualitative descriptive research method. The subjects of this research engaged 24 students of Biology Education Department of Universitas Islam Balitar and a Microbiology lecturer. The students participating in this study must have studied Microbiology courses. The techniques of collecting data included interviewing the subjects and administering questionnaires. The instruments used were interview sheet for the lecturer and questionnaire for the students to analyze the needs for Microbiology teaching materials. Interview data were analyzed descriptively, while questionnaire data were analyzed using percentage. The results showed that teaching materials for Microbiology course were not available. Therefore, development of image and text-based materials for Microbiology course is necessary; one of which is atlas.
\end{abstract}

Keywords: Needs Analysis, Teaching Materials, Microbiology, Atlas 
(p-ISSN 2527-7111; e-ISSN 2528-1615) no DOI : http://dx.doi.org/10.32528/bioma.v4i2.3162

\section{PENDAHULUAN}

Mikrobiologi merupakan salah satu mata kuliah wajib bagi mahasiswa Program Studi Pendidikan Biologi, Universitas Islam Balitar. National Research Council (2012) menyatakan bahwa, konten biologi yang dipelajari dalam mikrobiologi meliputi struktur dan prosesnya, hereditas, dan evolusi. Penguasaan topik-topik tersebut merupakan kewajiban bagi calon pendidik dalam bidang biologi dan IPA (Munandar et al. 2015).

Objek kajian dalam mikrobiologi adalah mikroorganisme. Mikroorganisme yang dipelajari meliputi bakteri, khamir, kapang, jamur, dan lichen (Subandi 2010). Diantara beberapa mikroorganisme tersebut, lichen merupakan salah satu jenis mikroorganisme yang sulit untuk dipelajari. Banyak mahasiswa yang masih sulit membedakan antara lichen yang lazim dikenal sebagai lumut kerak dengan lumut (Bryophyta).

Lichen adalah organisme yang berasal dari simbiosis organisme fotosintetik (alga Cyanophyta) dan fungi (Khare \& Rai, 2013; Peterson \& Ikeda, 2017; Muggia \& Grube, 2018). Organisme ini dapat tumbuh di berbagai permukaan tanah, benda, daun, batu (Khare \& Rai, 2013), material bekas, besi tua, kulit kayu, pohon, di pinggir sungai maupun di tepi pantai (Peterson \& Ikeda, 2017). Tubuh lichen dinamakan dengan thallus (Muggia \& Grube, 2018), ini sangat penting untuk identifikasi. Pada umumnya lichen yang menempel pada pohon berwarna hijau keabu - abuan, kuning, hijau biru, oranye, kuning cerah, coklat, dan bahkan hitam (Beaching \& Hill, 2007).

Hasil observasi awal menunjukkan bahwa ada kesulitan mahasiswa dalam memahami materi mikrobiologi. Hal tersebut ditunjukkan oleh 65\% mahasiswa memperoleh nilai C pada mata kuliah ini. Kesulitan belajar merupakan salah satu gejala yang nampak pada peserta didik ditandai dengan adanya prestasi belajar rendah atau di bawah nilai yang telah ditetapkan (Sugihartono 2012). Ada beberapa faktor yang dapat mempengaruhi mahasiswa dalam memahami materi perkuliahan diantaranya, model dan metode pembelajaran, media pembelajaran, bahan ajar, sarana prasarana untuk kegiatan pembelajaran, dan lain sebagainya (Sari \& Anantyarta, 2018).

Keberadaan bahan ajar dalam kegiatan pembelajaran menjadi penting karena bahan ajar sebagai salah satu faktor yang dapat mempengaruhi mahasiswa dalam memahami materi perkuliahan. Bahan ajar merupakan segala bentuk bahan yang dikumpulkan dari berbagai sumber belajar yang dibuat secara sistematis dan digunakan untuk membantu pendidik dalam melaksanakan kegiatan pembelajaran (Prastowo, 
2012). Menurut Dimas, dkk. (2016) penyusunan bahan ajar bertujuan untuk memudahkan pendidik dalam melaksanakan pembelajaran, membantu mahasiswa memperoleh alternatif bahan ajar selain buku teks yang terkadang sulit dipahami, dan menyediakan bahan ajar yang sesuai kurikulum dan karakteristik mahasiswa.

Beberapa temuan dalam proses pembelajaran mata kuliah mikrobiologi antara lain mahasiswa tidak memiliki bahan ajar untuk mendukung kegiatan pembelajaran. Mahasiswa mencari literatur terkait materi yang dibahas di internet dengan sumber yang tidak dapat dipertanggungjawabkan. Tidak jarang juga ditemukan mahasiswa yang mengakses internet untuk mencari literatur saat kegiatan diskusi kelas. Literatur yang diberikan untuk menunjang kegiatan perkualiahan mikrobiologi berupa buku teks berbahasa Inggris yang sebagian besar mahasiswa kesulitan untuk menerjemahkan sehingga mereka lebih sering mencari literatur lain berbahasa Indonesia melalui web di internet yang sumbernya kurang kredibel.

Tidak adanya bahan ajar jika dibiarkan terus menerus akan mempengaruhi kualitas pembelajaran dan mahasiswa akan kesulitan memahami materi mikrobiologi. Berdasarkan paparan permasalahan di atas maka perlu dikembangkan bahan ajar yang sesuai dengan karakteristik materi perkuliahan dan karakteristik mahasiswa sebagai pemakai bahan ajar. Penelitian ini bertujuan untuk menganalisis kebutuhan bahan ajar mata kuliah mikrobiologi pada program studi pendidikan biologi Universitas Islam Balitar Blitar.

\section{METODE}

Penelitian ini adalah penelitian deskriptif kualitatif dengan metode survei yang dilaksanakan pada bulan Juni-Juli 2019. Subjek penelitian ini adalah 24 mahasiswa program studi pendidikan Biologi Universitas Islam Balitar Blitar yang telah menempuh mata kuliah mikrobiologi dan dosen pengampu mata kuliah mikrobiologi. Teknik pengumpulan data dengan wawancara dan angket. Instrumen pengumpulan data menggunakan lembar angket yang berisi tentang kegiatan pembelajaran mikrobiologi yang pernah dialami mahasiswa dan analisis kebutuhan bahan ajar mikrobiologi serta instrumen wawancara untuk wawancara dosen pengampu mata kuliah mikrobiologi terkait kegiatan pembelajaran mikrobiologi dan bahan ajar yang digunakan. Angket analisis kebutuhan bahan ajar menggunakan dua bentuk. Bentuk pertama menggunakan 
skala Likert dengan acuan skor 4 adalah sangat setuju, skor 3 adalah setuju, skor 2 adalah kurang setuju, dan skor 1 adalah tidak setuju, sedangkan bentuk kedua menggunakan pilihan ya atau tidak. Data hasil angket analisis kebutuhan bahan ajar yang diperoleh kemudian dianalisis menggunakan rumus:

$\mathrm{P}=\sum \mathrm{X} \times 100 \%$

$\sum \mathrm{X} 1$

Keterangan:

$\mathrm{P} \quad=$ persentase

$\sum \mathrm{X}=$ Jumlah jawaban seluruh responden dalam satu item pertanyaan

$\sum \mathrm{X} 1=$ Jumlah jawaban ideal dalam satu item

$100 \%=$ konstanta $($ Sugiono, 2011)

\section{HASIL DAN PEMBAHASAN}

Berdasarkan angket analisis kebutuhan bahan ajar yang telah diisi mahasiswa diperoleh data yang diringkas pada Tabel 1. Data ringkasan hasil analisis kebutuhan bahan ajar ini merupakan hasil analisis dengan menggunakan rumus yang ada pada metode penelitian.

Tabel 1. Data Angket Mahasiswa tentang Analisis Kebutuhan Bahan Ajar Mikrobiologi

\begin{tabular}{llc}
\hline No & \multicolumn{1}{c}{ Indikator } & Persentase (\%) \\
\hline 1. & $\begin{array}{l}\text { Proses pembelajaran Mikrobiologi yang pernah saudara } \\
\text { dapatkan menggunakan media yang menarik }\end{array}$ & 37,50 \\
2. & $\begin{array}{l}\text { Pembelajaran Mikrobiologi seharusnya dilakukan dengan } \\
\text { menggunakan media atau bahan ajar visual yang jelas dan }\end{array}$ & 87,50 \\
& menarik & 75,00 \\
3. & Materi Mikrobiologi lebih menarik dan mudah dipahami jika \\
& $\begin{array}{l}\text { menggunakan gambar dan teks } \\
\text { 4. } \quad \text { Bahan ajar berbasis visual dapat menarik minat saya }\end{array}$ & 81,25 \\
& $\begin{array}{l}\text { mempelajari materi Mikrobiologi } \\
\text { 5. }\end{array}$ & 71,87 \\
& Pembelajaran Mikrobiologi memerlukan bahan ajar berbasis & \\
6. & Pembelajaran Mikrobiologi dilakukan dengan ceramah & 50,00
\end{tabular}


(p-ISSN 2527-7111; e-ISSN 2528-1615) no DOI : http://dx.doi.org/10.32528/bioma.v4i2.3162

\section{No}

\section{Indikator}

Persentase (\%)

7. Pembelajaran mikrobiologi menggunakan model pembelajaran

62,50

yang menarik

8. Pembelajaran mikrobiologi didukung dengan bahan ajar yang sesuai

9. Pembelajaran mikrobiologi menggunakan media yang menarik

10. Saya pernah memiliki bahan ajar untuk mendukung kegiatan pembelajaran mikrobiologi

11. Saya selalu mencari referensi bacaan mikrobiologi dari buku

12. Saya selalu mencari literatur tentang materi Mikrobiologi melalui internet

13. Saya mencari literatur mikrobiologi yang terpercaya dari internet

14. Saya mengakses web blog untuk mencari literatur tentang mikrobiologi

15. Saya mengakses jurnal dan artikel penelitian untuk mencari literatur tentang mikrobiologi

16. Saya mengakses $e$-book mikrobiologi untuk mencari literatur tentang mikrobiologi

17. Saya kesulitan mendapatkan literatur tentang materi Mikrobiologi

18. Bakteri merupakan objek kajian mikrobiologi yang sulit dipelajari

19. Fungi merupakan objek kajian mikrobiologi yang sulit dipelajari

20. Lichen merupakan objek kajian mikrobiologi yang sulit dipelajari

Berdasarkan hasil analisis diketahui bahwa pembelajaran Mikrobiologi yang telah dilakukan pada tahun ajaran sebelumnya sudah cukup menarik terbukti dari pernyatan $62,5 \%$ mahasiswa bahwa pembelajaran mikrobiologi sudah menggunakan model pembelajaran yang menarik. Akan tetapi sebanyak 37\% mahasiswa menyatakan 
bahwa media yang digunakan dalam pembelajaran Mikrobiologi kurang menarik serta $25 \%$ mahasiswa menyatakan belum tersedia bahan ajar yang sesuai. Sebanyak $62,5 \%$ mahasiswa merasa kesulitan untuk mendapatkan literatur mikrobiologi. Semua mahasiswa mencari literatur mikrobiologi melalui internet dan sebagian besar mencari pada laman blog.

Berdasarkan hasil wawancara yang dilakukan kepada dosen pengampu mata kuliah mikrobiologi didapatkan informasi bahwa pembelajaran dilaksanakan dengan diskusi presentasi. Mahasiswa dibagi menjadi beberapa kelompok dengan topik materi yang berbeda tiap kelompok untuk dipresentasikan. Dosen memberikan literatur berupa buku teks berbahasa Inggris yang kebanyakan mahasiswa tidak mau membaca karena sulit menerjemahkan. Mahasiswa tidak ada yang memiliki handbook, semua tugas mikrobiologi mengambil literatur melalui internet, dan bahan pembelajaran yang digunakan di kelas hanya power point. Kurangnya bahan ajar menyebabkan mahasiswa tidak dapat memperoleh banyak informasi untuk mengembangkan kompetensinya pada mata kuliah mikrobiologi.

Lebih lanjut dijelaskan pula oleh dosen pengampu mata kuliah mikrobiologi bahwa kajian dalam mata kuliah mikrobiologi pada program studi pendidikan Biologi Universitas Islam Balitar meliputi bakteri, khamir, kapang, jamur, dan lichen. Dari lima kajian tersebut yang paling sulit untuk dipelajari adalah lichen. Pendapat ini juga sejalan dengan hasil analisis angket bahwa 75\% mahasiswa menyatakan bahwa lichen merupakan objek kajian mikrobiologi yang sulit untuk dipelajari. Berdasarkan struktur morfologinya bakteri, khamir, kapang, dan jamur mudah untuk dibedakan, sedangkan lichen cukup sulit untuk dibedakan. Banyak mahasiswa yang sulit membedakan antara liken (lumut kerak) dengan lumut (Bryophyta). Berdasarkan kajiannya, diversitas lichen belum banyak tereksplor dan belum banyak dimanfaatkan secara optimal daripada bakteri, khamir, kapang, dan jamur. Waktu yang digunakan untuk membahas lichen dalam mata kuliah mikrobiologi juga sangat singkat yaitu hanya satu kali pertemuan tatap muka dan satu kali praktikum. Alokasi waktu tersebut tidak cukup jika digunakan untuk mempelajari diversitas lichen yang sangat banyak. Oleh karena itu, untuk mengoptimalkan proses pembelajaran mikrobiologi dan membantu mahasiswa memahami materi lichen, maka perlu dikembangkan bahan ajar lichen sebagai salah satu penunjang mata kuliah mikrobiologi. 
Berdasarkan hasil angket diketahui juga bahwa sebagian besar mahasiswa menginginkan pembelajaran mikrobiologi menggunakan media visual yang jelas dan menarik serta $75 \%$ mahasiswa memerlukan bahan ajar berbasis teks dan gambar. Mahasiswa lebih tertarik dan mudah memahami materi apabila menggunakan teks dan gambar. Gambar merupakan salah satu jenis media visual. Alat bantu visual bertujuan untuk memperkenalkan, membentuk, dan memperjelas pengertian atau konsep yang abstrak kepada siswa (Sudjana \& Rifa'i, 2007). Gambar juga dapat mengatasi ruang dan waktu, serta dapat mengatasi keterbatasan pengamatan (Sadiman, A.S, 2008). Menurut Sanaky (2009) bahan ajar berbasis gambar memiliki kelebihan diantaranya: a) sifatnya konkrit, lebih nyata dan menunjukkan pada pokok masalah jika dibandingkan dengan verbal, b) dapat mengatasi ruang dan waktu, artinya tidak semua benda, objek, dan peristiwa dapat dibawa ke kelas, dan pembelajaran tidak dapat dibawa ke objek tersebut, c) dapat mengatasi keterbatasan pengamatan panca indera, d) memperjelas suatu sajian masalah dalam bidang apa saja dan untuk tingkat usia berapa saja, dan e) lebih murah harganya, mudah didapatkan dan digunakan tanpa memerlukan peralatan khusus.

Bahan ajar berbasis gambar dan teks cocok dikembangkan untuk mata kuliah mikrobiologi karena dapat menampilkan mikroorganisme secara nyata apabila ada yang tidak dapat dipraktikumkan atau tidak dapat diamati secara langsung. Selain itu bahan ajar berbasis gambar dan teks akan sangat memudahkan kegiatan pembelajaran, khususnya untuk sekolah-sekolah atau perguruan tinggi yang sarana dan prasarananya kurang memadai, serta kesulitan memperoleh bahan amatan sehingga tidak mungkin akan dilakukan kegiatan praktikum. Putri (2017) menyebutkan bahwa pembelajaran dengan menggunakan bahan ajar berbasis gambar lebih efektif dibandingkan dengan pembelajaran menggunakan buku cetak yang biasa digunakan oleh kebanyakan pendidik. Bahan ajar yang tidak hanya memuat gambar tetapi juga dilengkapi dengan teks akan lebih mudah digunakan untuk memahami materi. Adanya teks pada bahan ajar akan membantu memperjelas deskripsi dari gambar.

Beberapa bahan ajar berbasis visual diantaranya atlas, modul, leaflet, lembar kerja siswa, buku ajar, brosur, dan lain sebagainya. Salah satu bahan ajar berbasis visual yang cocok dikembangkan untuk mata kuliah mikrobiologi adalah atlas. Atlas merupakan salah satu bahan ajar yang berisi foto secara lengkap dan berwarna serta 
terdapat penjelasan mengenai foto yang ditampilkan (Kusuma, Rohman \& Syamsuri, 2018). Atlas dapat digunakan untuk membantu proses pembelajaran saat bahan amatan asli tidak dapat ditemukan (Perry \& Mortan, 1998). Beberapa hasil penelitian telah mengungkap bahwa atlas merupakan salah satu bahan ajar yang efektif dan cocok digunakan untuk membelajarkan materi seperti plantae dan lichen yang strukturnya juga menyerupai plantae. Penelitian oleh Solikhah (2015) menggunakan atlas untuk membelajarkan materi keanekaragaman angiospermae, Nurjanah (2017) untuk materi tumbuhan lumut, Febriyani (2018) untuk materi jaringan tumbuhan, dan Iswanti (2019) untuk materi keanekaragaman tumbuhan spermatophyte.

Kajian materi dalam mata kuliah mikrobiologi meliputi organisme yang berukuran mikroskopis. Adanya bahan ajar atlas akan membantu memvisualisasikan mikroorganisme secara jelas dan menarik meskipun tidak dilakukan praktikum secara langsung karena atlas memuat foto berwarna beserta deskripsi singkat yang dapat menggambarkan kondisi amatan aslinya. Berdasarkan deskripsi analisis kebutuhan pada mahasiswa dan dosen mata kuliah mikrobiologi dan adanya beberapa keunggulan dari bahan ajar atlas, maka bahan ajar yang cocok dengan kurikulum mikrobiologi dan karakteristik mahasiswa program studi pendidikan Biologi Universitas Islam Balitar adalah atlas liken yang dapat digunakan sebagai salah satu penunjang mata kuliah mikrobiologi.

\section{KESIMPULAN DAN SARAN}

Kesimpulan dari penelitian ini adalah diperlukan pengembangan bahan ajar untuk mata kuliah mikrobiologi dan bentuk bahan ajar yang sesuai dengan analisis kebutuhan adalah atlas liken sebagai salah satu bahan ajar penunjang mata kuliah mikrobiologi. Saran dalam penelitian ini adalah setiap pendidik akan lebih baik jika menyediakan bahan ajar untuk setiap mata kuliah agar pembelajaran dapat berjalan lancar, mahasiswa dapat menemukan informasi atau literatur terkait materi yang sesuai kurikulum, dan mahasiswa mudah dalam memahami materi. 
(p-ISSN 2527-7111; e-ISSN 2528-1615) no DOI : http://dx.doi.org/10.32528/bioma.v4i2.3162

\section{DAFTAR PUSTAKA}

Beaching SQ, Hill R. 2007. Guide to Twelve Common \& Conspicuous Lichens of Georgia's Piedmont. Georgia: University of Georgia Atlanta (UGA).

Dimas, A., Cari, Suparmi, Sarwanto, Handhika, J. 2016. Profil Analisis Kebutuhan Bahan Ajar Mahasiswa Materi Dinamika Gerak pada Mata Kuliah Fisika Dasar. Seminar Nasional Fisika dan Aplikasinya 2016 Pascasarjana Ilmu Fisika Universitas Sebelas Maret Surakarta, 42-45.

Febriyani, R. 2018. Efektivitas Penggunaan Atlas Fotografi Preparat Jaringan Tumbuhan terhadap Hasil Belajar Siswa. Skripsi. Yogyakarta: Universitas Islam Negeri Sunan Kalijaga.

Iswanti, EN. 2019. Pengembangan Atlas Keanekaragaman Tumbuhan Spermatophyta untuk Memberdayakan Penguasaan Konsep Peserta Didik Kelas X SMA AlAzhar 3 Bandar Lampung. Skripsi. Lampung: Universitas Islam Negeri Raden Intan.

Khare, R., dan Rai, H. 2013. Lichens as indicators of habitat heterogeneity in a high altitude montaine pass (Sela pass) in Eastern Himalaya. UGC sponsored national conference on resource management \& its sustainable use. 22-23 Maret 2013. DOI: 10.13140/2.1.3311.6968.

Kusuma, RD, Rohman, F, Syamsuri, I. 2018. Pengembangan Atlas Keanekaragaman Hayati Berbasis Potensi Lokal untuk SMK Jurusan Pertanian. Jurnal Pendidikan: Teori, Penelitian, dan Pengembangan. Vol 3 (3): 296-301.

Muggia, L. dan Grube, M. 2018. Fungal Diversity in Lichens: From Extremotolerance to Interactions with Algae. Life. 2018, 8, 15: 1-14. doi:10.3390/life8020015.

Munandar K, Ibrahim M, Yuanita L. 2015. Model Learning Cycle Untuk Transformasi Pedagogik Pada Mahasiswa Pendidikan Biologi: Suatu Model Hipotetik Untuk Meningkatkan Profesionalisme Calon Guru. Seminar Nasional Pendidikan Biologi 2015. Malang, 21 Maret 2015.

National Research Council. 2012. A Framework for K-12 Science Education: Practies, Crosscutting Concepts, and Core Ideas. Washington DC: The National Academics Press. 
(p-ISSN 2527-7111; e-ISSN 2528-1615) no DOI : http://dx.doi.org/10.32528/bioma.v4i2.3162

Nurjannah, S. 2017. Pengembangan Atlas Tumbuhan Lumut Berbasis Android sebagai Bahan Ajar Biologi pada Materi Plantae untuk SMA/MA Kelas X. Skripsi. Malang: Universitas Muhammadiyah Malang.

Perry, JW, dan Morton, D. 1998. Photo Atlas for Botany. USA: Wadsworth Publishing Company.

Peterson, E. B. dan D. Ikeda. 2017. An introduction to lichens and their conservation in California. California: California Academy of Sciences, San Francisco. DOI: 10.13140/RG.2.2.32222.13128.

Prastowo, A. (2012). Panduan Kreatif Membuat Bahan Ajar Inovatif. Yogyakarta: Diva Press.

Putri, IW. 2017. Pengembangan Bahan Ajar IPS Berbasis Gambar Kelas III Sekolah Dasar. (Online). (http://repository.upy.ac.id/1556/1/Artikel.pdf), diakses 29 Maret 2020.

Sadiman, AS. 2008. Media Pendidikan: Pengertian, Pengembangan, dan Pemanfaatannya. Jakarta: Raja Grafindo Persada.

Sanaky, HAH. 2009. Media Pembelajaran. Yogyakarta: Safiria Insania Press

Sari, NK, dan Anantyarta, P. 2018. Pengembangan Petunjuk Praktikum Histologi Program Studi Pendidikan Biologi. BIOMA: Jurnal Biologi dan Pembelajaran Biologi. Vol 3 (2): 124-138.

Sholikhah, AN. 2015. Atlas Keanekaragaman Angiospermae Sekitar Sekolah dan Pengembangan LKS Inkuiri Terbimbing untuk SMA/MA. Skripsi. Yogyakarta: Universitas Islam Negeri Sunan Kalijaga.

Subandi. 2010. Mikrobiologi: Perkembangan, Kajian, dan Pengamatan dalam Persfektif Islam. Jakarta: Rosda.

Sudjana, N, dan Rifa'I, A. 2007. Teknologi Pendidikan. Bandung: Sinar Baru Algensindo

Sugihartono, Fathiyah KN, Harahap F, Setiawati FA, Nurhayati SR. 2012. Psikologi Pendidikan. Yogyakarta: UNY Press.

Sugiyono. 2011. Metode Penelitian Pendidikan Pendekatan Kuantitatif, Kualitatif, dan $R \& D$. Bandung: Alfabeta. 